\title{
Penerapan Model Regresi Data Panel: Determinan PDRB Sektor Unggulan di Provinsi Riau Tahun 2015-2019
}

\author{
(Applied Panel Regression Model : Determinants GDRP of the Leading Sector in Riau Province in \\ 2015-2019)
}

\author{
Ali Imran Mansyur ${ }^{1 *}$, Agung Priyo Utomo² \\ 1,2 Politeknik Statistika STIS \\ Jalan Otto Iskandardinata No.64C, Jatinegara, Jakarta Timur \\ Daerah Khusus Ibukota Jakarta 13330 \\ E-mail: ${ }^{1} 111810146 @$ stis.ac.id, ${ }^{2}$ agung@stis.ac.id
}

\begin{abstract}
ABSTRAK
Komponen perekonomian terdiri dari beberapa sektor, masing-masing sektor memberikan kontribusi yang berbedabeda. Banyaknya sektor ekonomi sehingga harus dilakukan analisis untuk melihat sektor ekonomi unggulan yang potensinya dapat dioptimalkan untuk meningkatkan perekonomian Provinsi Riau. Tujuan penelitian ini untuk mengetahui sektor unggulan di Provinsi Riau dan gambaran umumnya serta faktor-faktor yang memengaruhi tingkat PDRB sektor unggulan tersebut di Provinsi Riau tahun 2015-2019. Dengan analisis overlay, yaitu penggabungan antara analisis Location Quotient dan Model Rasio Pertumbuhan diperoleh sektor unggulan di Provinsi Riau adalah sektor pertanian dan industri pengolahan. Melalui analisis regresi data panel dengan FEM, diperoleh hasil tenaga kerja sektor pertanian, inflasi sektor pertanian, dan luas lahan pertanian berpengaruh signifikan, sedangkan panjang jalan tidak berpengaruh signifikan terhadap PDRB sektor pertanian. Sementara itu, tenaga kerja sektor industri pengolahan, inflasi sektor industri pengolahan, dan jumlah unit usaha berpengaruh signifikan, sedangkan panjang jalan tidak berpengaruh signifikan terhadap PDRB industri pengolahan di Provinsi Riau tahun 2015-2019.
\end{abstract}

Kata kunci: pendapatan regional, sektor unggulan, data panel

\begin{abstract}
The economic components consist of several sectors, each sector contributes differently. Lot of sectors made it necessary to do analysis to overview the leading economic sectors whose potential can be increased to improve the economy of Riau Province. The purpose of this study is to determine the leading sector in Riau Province and its general description and factors that influence the level of GDRP of the leading sector in Riau Province in 2015-2019. With overlay analysis, which is a combination of Location Quotient Analysis and Capital Ratio Analysis, the leading sectors in Riau Province are agricultural and manufacturing sectors. By using Panel data regression with fixed effect model, the result shows that agricultural labor force, agricultural sector inflation, and agricultural land area have a significant effect, while the road length has no significant effect on the GDP of agricultural sector. Meanwhile, manufacturing labor force, manufacturing sector inflation and the number of establishments have a significant effect, while the road length has no significant effect on the GDP of manufacturing sector in Riau Province in 2015-2019.
\end{abstract}

Keywords: regional income, leading sector, panel data

\section{PENDAHULUAN}

Saat ini Indonesia tengah melakukan pembenahan di segala bidang, salah satunya dalam bidang ekonomi. Beberapa kebijakan yang dilaksanakan seperti reformasi birokrasi dan struktural, pembangunan infrastruktur Indonesia sentris, dan penggunaan APBN yang tepat sasaran (Kantor Staf Presiden, 2019). Kebijakan tersebut merupakan wujud implementasi pemerintah dalam melaksanakan dan mendorong pembangunan nasional agar semakin meningkat. Akan tetapi, pemerintah pusat tidak dapat menjalankan pembangunan tanpa adanya peran aktif dari pemerintah daerah, sebagai negara kesatuan Indonesia memiliki rencana pembangunan yang meliputi rencana pembangunan nasional dan daerah.

Sejak era reformasi, terjadi penyesuaian sistem pemerintahan yang awalnya pola sentralisasi menjadi desentralisasi atau dikenal dengan otonomi daerah. Otonomi daerah bertujuan memberikan kesempatan yang luas bagi pemerintah daerah dalam menjalankan pembangunan dan meningkatkan daerahnya. Setiap daerah memiliki potensi berbeda, sehingga pemerintah daerah harus menggali untuk memperoleh sektor ekonomi yang mampu menjadi unggulan di daerahnya. Menurut BPS, salah satu indikator yang dibutuhkan dalam mengetahui perekonomian suatu wilayah yaitu Produk Domestik Regional Bruto. 
Riau merupakan daerah yang memiliki sumber daya alam melimpah, baik sumber daya yang dapat diperbaharui maupun yang tidak. Pembangunan perekonomian yang diproksikan dari data PDRB menunjukkan bahwa Riau memiliki tingkat PDRB yang tinggi daripada provinsi lain di Pulau Sumatera.

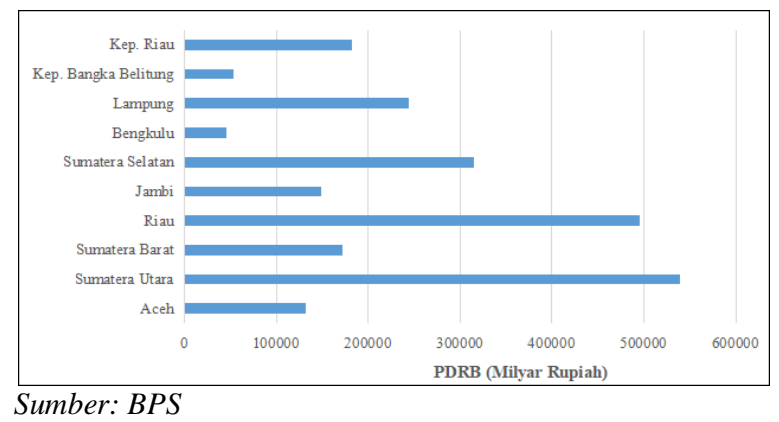

Gambar 1. PDRB ADHK 2010 berdasarkan provinsi di Pulau Sumatera tahun 2019

Gambar 1 terlihat bahwa Provinsi Riau memiliki PDRB yang cukup tinggi dibandingkan provinsi lainnya di Pulau Sumatera yaitu sebesar 495.845,91 miliar rupiah atau berada urutan kedua setelah Provinsi Sumatera Utara. Namun, dilihat dari laju pertumbuhan ekonomi, Riau merupakan provinsi di Pulau Sumatera yang pertumbuhan ekonominya sangat lambat.

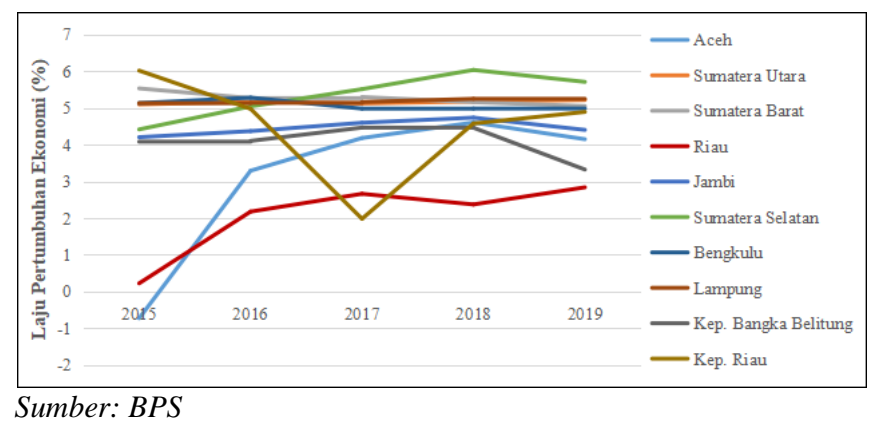

Gambar 2. Laju pertumbuhan ekonomi berdasarkan provinsi di Pulau Sumatera 2015-2019

Gambar 2 terlihat bahwa laju pertumbuhan ekonomi Provinsi Riau tahun 2015-2019 cenderung lebih rendah dari provinsi lain di Pulau Sumatera. Laju pertumbuhan ekonomi Provinsi Riau hanya berkisar antara 2-3 persen saja, bahkan pada tahun 2015 hanya mencapai 0.22 persen. Walaupun PDRB tergolong tinggi tetapi laju pertumbuhan ekonomi Provinsi Riau tergolong sangat lambat. Hal tersebut menandakan bahwa pemerintah daerah masih harus menggali dan mengembangkan sektor ekonomi yang potensial untuk meningkatkan ekonomi daerah secara optimal dengan strategi pembangunan yang baik.

Tingkat PDRB berdasarkan kabupaten/kota di Provinsi Riau dari tahun 2015-2019 cenderung mengalami peningkatan setiap tahun. Akan tetapi, laju pertumbuhan setiap kabupaten/kota sangat bervariasi. Berikut laju pertumbuhan PDRB setiap kabupaten/kota.

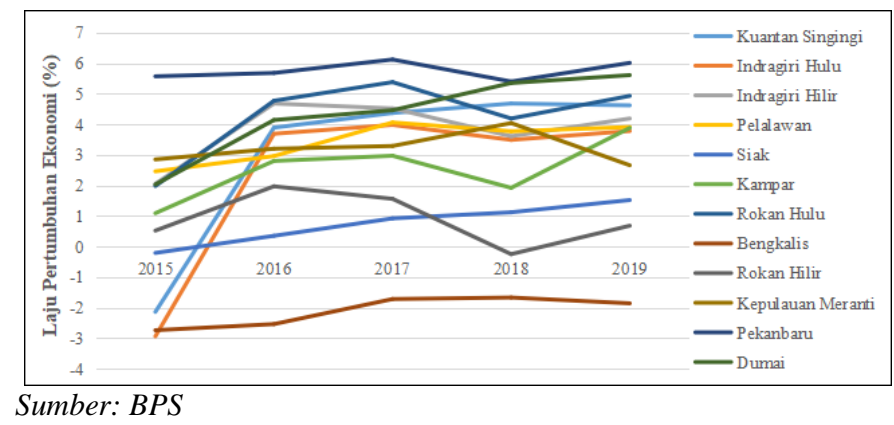

Gambar 3. Laju pertumbuhan ekonomi berdasarkan kabupaten/kota di Provinsi Riau tahun 2015-2019

Gambar 3 diperoleh informasi bahwa laju pertumbuhan ekonomi dari tahun 2015-2019 setiap kabupaten/kota relatif berfluktuatif. Hanya Kabupaten Siak dan Kota Dumai dengan laju pertumbuhan selalu mengalami peningkatan. Hal ini menandakan bahwa laju pertumbuhan ekonomi antar kabupaten/kota di Provinsi Riau sangat bervariasi. 
Komponen perekonomian terdiri dari beberapa sektor, setiap sektor memberikan kontribusi yang berbeda dalam pembentukan PDRB. Banyaknya sektor ekonomi sehingga harus dilakukan analisis lebih lanjut untuk melihat sektor ekonomi unggulan yang dapat lebih dioptimalkan untuk meningkatkan perekonomian Provinsi Riau. Sjafrizal (2012) menyatakan bahwa sektor unggulan adalah pemimpin dan penggerak utama perekonomian wilayah, sehingga sektor unggulan disebut juga sebagai sektor kunci atau sektor pemimpin (Syarifuddin dan Dewi, 2014). Oleh karena itu, penelitian ini bertujuan untuk mengetahui sektor unggulan di Provinsi Riau dan gambaran umumnya serta faktor-faktor yang memengaruhi tingkat pendapatan regional sektor unggulan tersebut di Provinsi Riau tahun 2015-2019.

Penelitian tentang sektor unggulan telah dilaksanakan oleh banyak peneliti. Penelitian Basuki dan Gayatri (2009) \& Yusuf (1999) menggunakan analisis overlay, yaitu menggabungkan antara analisis Location Quotient dan Model Rasio Pertumbuhan untuk menentukan sektor unggulan berdasarkan kriteria kontribusi dan kriteria pertumbuhan. Kemudian penelitian mengenai faktor-faktor yang memengaruhi PDRB, seperti Dachi (2016) menjelaskan kenaikan jumlah tenaga kerja akan meningkatkan produksi yang kemudian meningkatkan sumbangan terhadap PDRB. Pranata (2014) menjelaskan semakin tinggi inflasi akan berdampak pada harga barang di pasaran yang akan membuat daya beli masyarakat turun. Hal ini mengakibatkan PDRB juga akan turun. Sitorus (2019) menjelaskan lahan yang lebih luas membutuhkan lebih banyak tenaga kerja yang akan menambah tingkat produksi. Yusnanto (2010) menjelaskan bahwa pertumbuhan unit usaha akan menambah kontribusi terhadap PDRB. Rokhmat et al. (2020) menjelaskan bahwa jalan memiliki pengaruh yang kecil, hal ini disebabkan karena panjang jalan relatif konstan dari tahun ke tahun.

\section{METODE}

\section{Landasan Teori}

\section{Produk Domestik Regional Bruto}

PDRB adalah total nilai tambah yang dihasilkan dari seluruh unit usaha di suatu wilayah tertentu. PDRB juga memberikan informasi mengenai tingkat pertumbuhan perekonomian dan potensi dari suatu daerah.

Faktor-Faktor yang Memengaruhi Produk Domestik Regional Bruto

Samuelson dan Nordhaus (2010) menjelaskan terdapat empat unsur yang dapat meningkatkan perekonomian, yaitu : (1) SDM; (2) SDA; (3) Modal; (d) Perubahan dan Inovasi Teknologi. Teori Keynesian mengatakan bahwa untuk jangka pendek output nasional dipengaruhi oleh permintaan agregat. Permintaan agregat ini dipengaruhi terhadap harga berdasarkan hukum permintaan (Ardiansyah dalam Murni, 2006).

1. Tenaga Kerja

Dalam proses produksi, tenaga kerjalah yang menggerakkan, menjalankan, dan mengoperasikan seluruh sumber produksi untuk menghasilkan barang bernilai yang akan memengaruhi tingkat PDRB di suatu daerah. Dachi dalam Todaro (2000) tenaga kerja yang semakin besar berarti tingkat produksi akan meningkat.

2. Inflasi

Inflasi merupakan kenaikan harga barang dan jasa secara umum yang terjadi terus-menerus. Pengukuran inflasi di Indonesia umumnya mengggunakan IHK. Akan tetapi, PDB deflator dan IHPB juga bisa digunakan sebagai pendekatan untuk mengukur inflasi. Tingginya inflasi akan berdampak pada harga barang di pasaran. Harga barang yang tinggi akan berdampak pada proses produksi dan rendahnya daya beli masyarakat sehingga akan menurunkan pendapatan (Pranata, 2014).

3. Modal

Modal adalah barang atau produk yang digunakan untuk menghasilkan produk selanjutnya. Berdasarkan sifatnya, modal terbagi dua yaitu (1) Modal Tetap adalah modal yang mampu digunakan berulang kali dan kuantitasnya cenderung tidak mudah berubah, seperti tanah/lahan, bangunan, pabrik, dan lain sebagainya; (2) Modal lancar adalah modal yang jika digunakan akan habis dalam satu kali proses produksi, seperti bibit, pupuk, bahan baku, dan lain sebagainya.

Modal tetap memiliki peran sangat penting dalam proses produksi, misalnya lahan pertanian sebagai modal tetap untuk sektor pertanian sangat memengaruhi tingkat produksi yang dihasilkan. Sitorus (2019) dalam penelitiannya bahwa luas lahan pertanian memiliki pengaruh positif terhadap PDRB sektor pertanian. Peningkatan luas lahan akan mendorong naiknya produktivitas pada sektor pertanian.

Bangunan atau unit usaha sebagai modal tetap untuk sektor industri pengolahan yang berfungsi menjadi tempat segala proses produksi dijalankan. Yusnanto (2010) menjelaskan bahwa jumlah unit usaha berpengaruh 
signifikan dan positif terhadap PDRB sektor industri pengolahan. Pertumbuhan unit usaha akan menambah kontribusi terhadap PDRB.

4. Jalan

Jalan dibutuhkan dalam menghubungkan antar satu daerah dengan daerah lain sehingga dengan mudah dapat mendistribusikan hasil produksi kepada konsumen. Penelitian Rokhmat et al. (2020) menyimpulkan bahwa infrastruktur jalan berpengaruh positif terhadap PDRB.

\section{Metode Analisis}

Metode analisis yang digunakan adalah analisis deskriptif dan inferensia. Penentuan sektor unggulan menggunakan analisis deskriptif dengan analisis overlay, yaitu menggabungkan hasil analisis antara Location Quotient dan Model Rasio Pertumbuhan. Kedua kriteria tersebut dibutuhkan untuk melihat gambaran struktur ekonomi wilayah yang potensial. Sedangkan untuk mengetahui variabel-variabel yang berpengaruh terhadap PDRB sektor unggulan digunakan analisis regresi data panel.

\section{Analisis Location Quotient (LQ)}

Analisis LQ adalah analisis untuk melihat basis ekonomi wilayah terutama dari kriteria kontribusi (Yusuf, 1999). Sektor basis merupakan sektor ekonomi yang mampu melayani pasar di wilayah sendiri maupun di luar wilayah tersebut, sedangkan sektor nonbasis merupakan sektor ekonomi yang belum mampu mencukupi pasar di daerah tersebut. Berikut formula analisis LQ:

$$
L Q=\frac{V_{i k} / V_{k}}{V_{i p} / V_{p}}
$$

Keterangan:

$\mathrm{V}_{\mathrm{ik}}$ : PDRB sektor i daerah $\mathrm{k}$ (provinsi)

$\mathrm{V}_{\mathrm{k}}$ : PDRB total daerah $\mathrm{k}$ (provinsi)

$V_{\text {ip : }}$ PDB sektor i daerah referensi $p$ (Indonesia)

$\mathrm{V}_{\mathrm{p}}$ : PDB total daerah referensi $\mathrm{p}$ (Indonesia)

Formula di atas menghasilkan bahwa jika koefisien LQ $>1$ merupakan sektor basis dan koefisien LQ $\leq$ 1 merupakan sektor nonbasis.

\section{Analisis Model Rasio Pertumbuhan (MRP)}

Analisis MRP adalah analisis untuk melihat kondisi sektor ekonomi perencanaan wilayah dengan lebih melihat pada kriteria pertumbuhan. Analisis ini dibagi 2 yakni Rasio Pertumbuhan Wilayah Referensi $\left(\mathrm{RP}_{\mathrm{r}}\right)$ dan Rasio Pertumbuhan Wilayah Studi $\left(\mathrm{RP}_{\mathrm{s}}\right.$ ) (Yusuf, 1999). Namun, dalam penelitian ini yang digunakan hanya $\mathrm{RP}_{\mathrm{s}}$ yang merupakan rasio laju pertumbuhan suatu sektor ekonomi di wilayah penelitian dengan laju pertumbuhan suatu sektor ekonomi di wilayah referensi. Dirumuskan sebagai berikut :

$$
R P_{s}=\frac{\Delta E_{i j} / E_{i j,(t-1)}}{\Delta E_{i R} / E_{i R,(t-1)}}
$$

Keterangan :

$\Delta E_{i j}$ : Selisih PDRB sektor $i$ tahun t dengan tahun t-1 di wilayah penelitian

$\Delta E_{i R}$ : Selisih PDRB sektor $i$ tahun $\mathrm{t}$ dengan tahun $\mathrm{t}-1$ di wilayah referensi

$E_{i j,(t-1)}$ : PDRB sektor $i$ tahun t-1 di wilayah penelitian

$E_{i R,(t-1)}$ : PDRB sektor $i$ tahun t-1 di wilayah referensi

Nilai $R P_{s}>1$ berarti pertumbuhan sektor tersebut di wilayah penelitian lebih tinggi daripada pertumbuhan sektor yang sama di wilayah referensi. Sedangkan jika nilai $\mathrm{RP}_{\mathrm{s}}<1$ berarti pertumbuhan sektor tersebut di wilayah penelitian lebih kecil daripada pertumbuhan sektor yang sama di wilayah referensi.

\section{Analisis Overlay}

Analisis overlay adalah analisis untuk menarik suatu keputusan dengan mengombinasikan beberapa hasil analisis. Dalam penelitian ini analisis overlay yang digunakan adalah mengombinasikan antara analisis LQ dan MRP. Jadi, termasuk sektor unggulan jika memenuhi kriteria, yaitu hasil analisis LQ nilainya lebih besar dari $1(\mathrm{LQ}>1)$ dan hasil $\mathrm{RP}_{\mathrm{s}}$ bernilai lebih besar dari $1\left(\mathrm{RP}_{\mathrm{s}}>1\right)$. Tujuan dari analisis ini untuk melihat gambaran kegiatan sektor unggulan berdasarkan kriteria kontribusi (analisis LQ) dan kriteria pertumbuhan (analisis MRP) (Yusuf, 1999). 


\section{Analisis Regresi Data Panel}

Data panel merupakan data yang berisi pengamatan berulang dari satu set unit cross section. Dalam mengestimasi parameter analisis regresi data panel dapat menggunakan tiga model estimasi, yaitu Common Effect Model, Fixed Effect Model, dan Random Effect Model (Baltagi, 2005).

1. Common Effect Model (CEM)

\section{Fixed Effect Model (FEM)}

\section{Random Effect Model (REM)}

$$
y_{i t}=\alpha+x_{i t}^{\prime} \beta+u_{i t}
$$

$$
y_{i t}=\left(\alpha+\mu_{i}\right)+x_{i t}^{\prime} \beta+v_{i t}
$$

$$
y_{i t}=\alpha+x_{i t}^{\prime} \beta+u_{i t}
$$

Di mana:

$$
u_{i t}=\mu_{i}+v_{i t}
$$

Keterangan:

$y_{i t}$ : Variabel tidak bebas pada individu ke-i periode ke-t

$\alpha$ : Intersep

$\beta$ : Vektor slope variabel bebas

$X_{i t}^{\prime}$ : Vektor observasi variabel bebas

$\mu_{i}:$ efek individu

$v_{i t}:$ Error regresi

$u_{i t}:$ Error komposit

Tahapan pertama dalam analisis regresi data panel yaitu pemilihan model terbaik menggunakan Uji Chow, kemudian dilanjutkan dengan Uji Hausman atau Uji Breusch Pagan Lagrange Multiplier. Selanjutnya, dilakukan pemeriksaan struktur matriks varians-kovarians residual jika model terpilih adalah Fixed Effect Model dengan menggunakan Uji Lagrange Multiplier (LM) dan Uji $\lambda_{L M}$. Pengujian ini dilakukan karena struktur varians-kovarians untuk FEM ada tiga yaitu struktur homoskedastik, struktur heteroskedastik tanpa korelasi antar individu, dan struktur heteroskedastik dengan korelasi antar individu. Berikutnya dilakukan uji asumsi klasik. Pada tahap akhir dilakukan pengujian keberartian model yang terdiri dari Uji Simultan (Uji F), Uji Parsial (Uji t) dan koefisien Determinasi $\left(\mathrm{R}^{2}\right)$.

\section{Data dan Sumber Data}

Penelitian ini menggunakan data panel dengan data time series sebanyak 5 tahun dari 2015-2019 dan data cross section sebanyak 12 kabupaten/kota di Provinsi Riau . Dalam menentukan sektor unggulan, penelitian dilakukan pada unit pengamatan provinsi dan Indonesia sebagai daerah acuan. Pada analisis inferensia, unit pengamatan yang digunakan adalah tingkat kabupaten/kota. Variabel dependen yang digunakan adalah PDRB sektor unggulan. Variabel independen dalam penelitian ini adalah tenaga kerja sektor unggulan, inflasi sektor unggulan, modal tetap sektor unggulan, dan panjang jalan. Sumber data yang digunakan dari Publikasi Badan Pusat Statistika Provinsi Riau.

\section{HASIL DAN PEMBAHASAN}

\section{Identifikasi Sektor Unggulan di Provinsi Riau}

Dalam menentukan sektor unggulan di Provinsi Riau, dilakukan analisis overlay atau menggabungkan hasil dari analisis LQ dan MRP. Hasil perhitungan analisis overlay dapat diketahui pada gambar berikut ini :

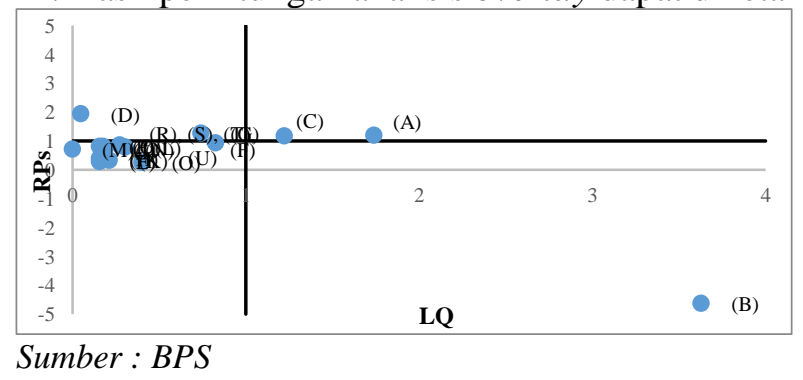

Gambar 4. Analisis overlay sektor perekonomian Provinsi Riau tahun 2015-2019 
Jadi, berdasarkan analisis overlay diperoleh dua sektor ekonomi unggulan di Provinsi Riau yaitu sektor (A) pertanian, kehutanan, dan perikanan; dan sektor (C) industri pengolahan.

\section{Gambaran Umum Sektor Pertanian}

Gambar 5 berikut menunjukkan PDRB sektor pertanian kabupaten/kota selalu mengalami peningkatan. Wilayah yang memiliki PDRB sektor pertanian tertinggi adalah Kabupaten Indragiri Hilir. Kabupaten Indragiri Hilir memiliki PDRB sektor pertanian sejak awal periode penelitian sebesar 17.753,9 miliar rupiah hingga mencapai 20.445,2 miliar rupiah pada tahun 2019. Tingginya tingkat PDRB sektor pertanian di Kabupaten Indragiri Hilir tidak terlepas dari peranan produksi komoditas unggulan yang tinggi yaitu kelapa.

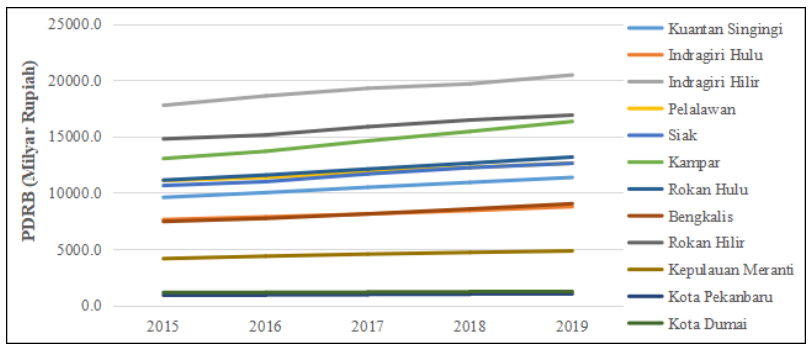

Sumber: BPS

Gambar 5. PDRB ADHK 2010 sektor pertanian

kabupaten/kota di Provinsi Riau tahun 2015-2019

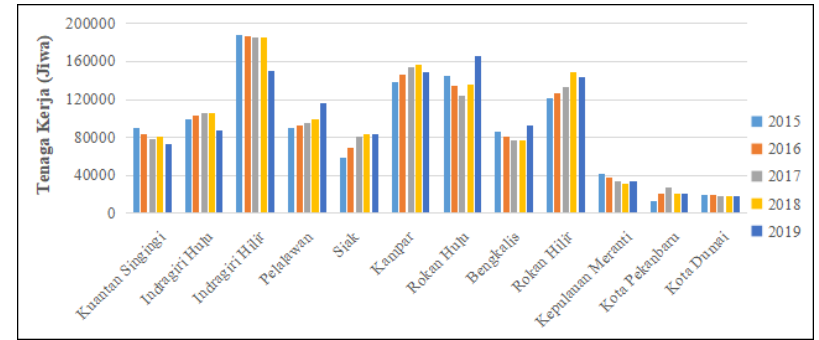

Sumber: BPS

Gambar 6. Tenaga kerja sektor pertanian kabupaten/kota di Provinsi Riau tahun 2015-2019

Gambar 6 menunjukkan tenaga kerja sektor pertanian antar kabupaten/kota cenderung berfluktuatif. Kabupaten Indragiri Hilir memiliki rata-rata banyak tenaga kerja sektor pertanian tertinggi sebesar 179.026 jiwa. Sedangkan terendah berada di Kota Dumai dan Kota Pekanbaru yang hanya memiliki rata-rata banyak tenaga kerja sektor pertanian masing-masing sebesar 18.618 dan 20.526 jiwa.

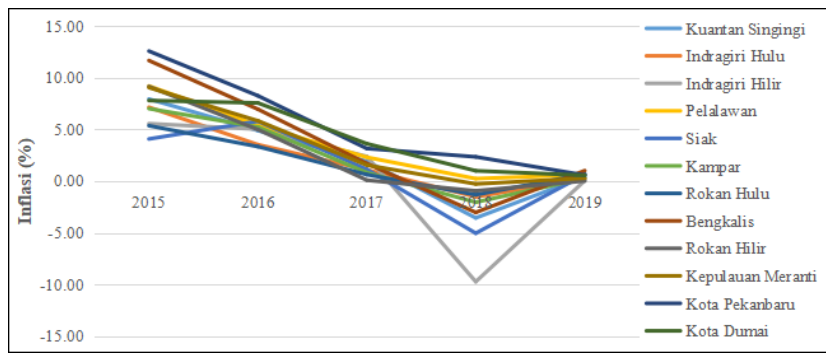

Sumber: BPS

Gambar 7. Inflasi sektor pertanian kabupaten/kota di Provinsi Riau tahun 2015-2019

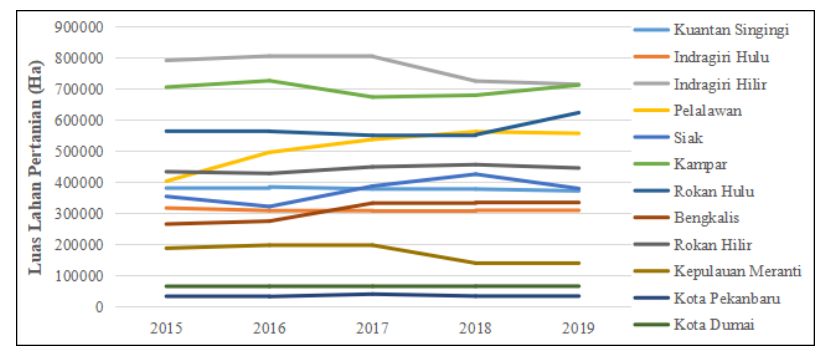

Sumber: BPS

Gambar 8. Luas lahan pertanian kabupaten/kota di Provinsi Riau tahun 2015-2019

Gambar 7 inflasi pada sektor pertanian kabupaten/kota cenderung berfluktuatif. Inflasi tertinggi terjadi pada tahun 2015. Dua kabupaten/kota mengalami inflasi mencapai dua digit yaitu Kota Pekanbaru mencapai angka 12,59 persen dan Kabupaten Bengkalis 11,67 persen pada tahun 2015. Secara umum pada tahun 2015 hingga 2018 inflasi mengalami penurunan drastis, bahkan pada tahun 2018 beberapa kabupaten/kota mengalami deflasi. Kemudian, rata-rata kabupaten/kota pada tahun 2019 kembali mengalami inflasi.

Luas lahan pertanian yang digunakan adalah total dari luas areal tanaman perkebunan, luas panen tanaman sayuran, luas lahan baku sawah, ladang/huma, lahan tegal/kebun, dan lahan sementara tidak diusahakan dalam satuan hektar. Dari gambar 8 dapat dilihat bahwa luas lahan pertanian kabupaten kota di Provinsi Riau cenderung berfluktuatif. Kabupaten Indragiri Hilir merupakan wilayah dengan luas lahan pertanian terbesar dengan rata-rata mencapai 767.936,8 Ha. Lahan pertanian Kabupaten Indragiri Hilir didominasi oleh lahan perkebunan sekitar 83,47 persen dari total luas lahan pertanian wilayah tersebut.

\section{Gambaran Umum Sektor Industri Pengolahan}

Gambar 9 dapat dilihat PDRB sektor industri pengolahan kabupaten/kota. Wilayah dengan PDRB sektor industri pengolahan tertinggi adalah Kabupaten Siak sebesar 21.072,7 miliar rupiah pada tahun 2015 dan tahun 2019 mencapai sebesar 23.673,2 miliar rupiah. Kabupaten Siak merupakan salah satu sentra industri pengolahan di Provinsi Riau terutama industri makan dan minum, industri kertas, barang dari kertas, percetakan dan reproduksi media rekaman, serta berbagai industri pengolahan lainnya. 


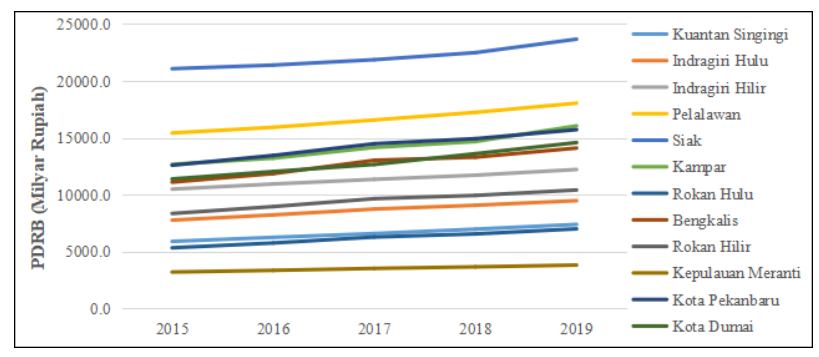

Sumber: BPS

Gambar 9. PDRB ADHK 2010 sektor industri pengolahan kabupaten/kota di Provinsi Riau tahun 2015-2019

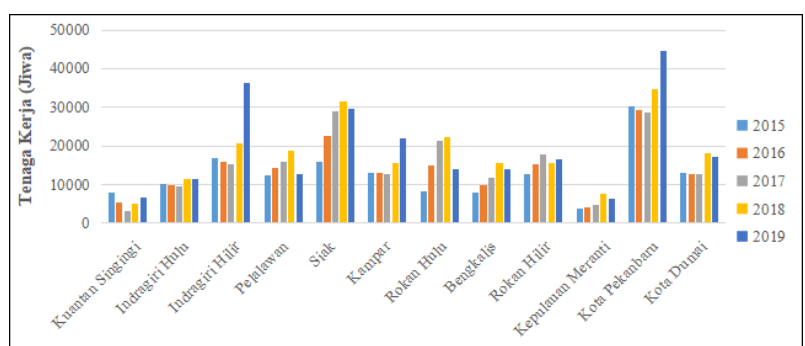

Sumber: BPS

Gambar 10. Tenaga kerja sektor industri pengolahan kabupaten/kota di Provinsi Riau tahun 2015-2019

Gambar 10 menunjukkan tenaga kerja sektor industri pengolahan antar kabupaten/kota di Provinsi Riau yang juga cenderung berfluktuatif. Kota Pekanbaru memiliki rata-rata jumlah tenaga kerja sektor industri pengolahan tertinggi sebanyak 33.530 jiwa. Sedangkan terendah berada di Kabupaten Kepulauan Meranti dan Kabupaten Kuantan Singingi yang hanya memiliki rata-rata jumlah tenaga kerja sektor industri pengolahan masing-masing sebanyak 5.333 dan 5.641 jiwa.

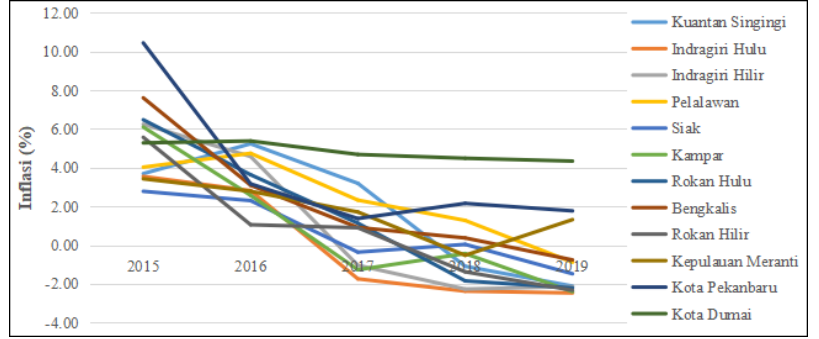

Sumber: BPS

Gambar 11. Inflasi sektor industri pengolahan kabupaten/kota di Provinsi Riau tahun 2015-2019

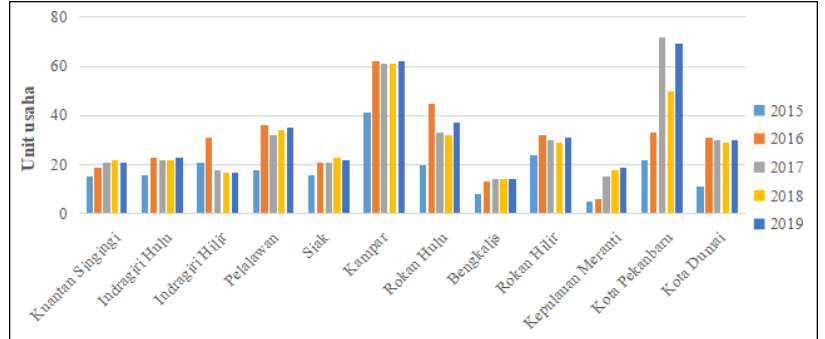

Sumber: BPS

Gambar 12. Jumlah unit usaha kabupaten/kota di Provinsi Riau tahun 2015-2019

Gambar 11 menunjukkan pergerakan inflasi pada sektor industri pengolahan di kabupaten/kota Provinsi Riau tahun 2015-2019 yang berfluktuatif. Pada tahun 2015 dapat dilihat bahwa Kota Pekanbaru mengalami inflasi tertinggi hingga mencapai dua digit yaitu sebesar 10,45 persen. Pada tahun 2016-2019 Kota Dumai selalu menempati posisi inflasi tertinggi. Berbeda dengan kabupaten/kota lain yang inflasinya berfluktuatif, Kota Dumai cenderung mengalami inflasi yang stabil.

Jumlah unit usaha yang digunakan adalah jumlah unit yang termasuk dalam industri besar dan sedang. Gambar 12 menunjukkan terdapat dua kabupaten yang memiliki jumlah unit usaha industri besar sedang terbanyak yaitu Kabupaten Kampar dan Kota Pekanbaru. Kabupaten Kampar memiliki jumlah unit usaha industri besar sedang sebesar 41 unit pada tahun 2015 dan tahun 2016 meningkat menjadi 62 unit. Kemudian pada tahun 2017-2019 jumlah unit usaha industri besar sedang di Kabupaten Kampar cenderung tetap antara 61 dan 62 unit. Sedangkan jumlah unit usaha pada Kota Pekanbaru mengalami fluktuasi. Pada tahun 2015 jumlah unit usaha di Kota Pekanbaru sebesar 22 unit dan meningkat pada tahun 2016 menjadi 33 unit. Kemudian meningkat drastis pada tahun 2017 mencapai 72 unit. Akan tetapi, pada tahun 2018 mengalami penurunan menjadi 50 unit. Kemudian meningkat lagi menjadi 69 unit pada tahun 2019.

\section{Gambaran Umum Panjang Jalan}

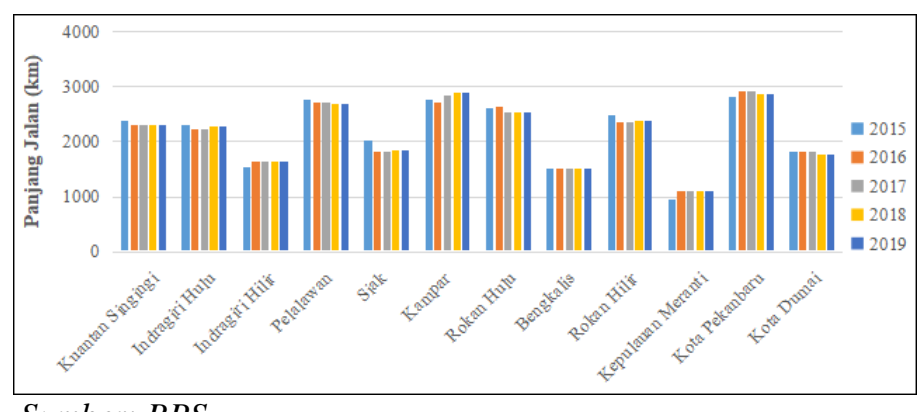

Sumber: BPS

Gambar 13. Panjang jalan kabupaten/kota di Provinsi Riau tahun 2015-2019 
Gambar 13 menunjukkan perkembangan infrastruktur jalan selama periode 2015-2019 di kabupaten/kota Provinsi Riau yang cenderung tidak berubah. Pembangunan infrastruktur jalan memerlukan waktu yang lama dan dana yang tidak sedikit sehingga perkembangannya tidak berubah signifikan.

\subsection{Variabel-Variabel yang Memengaruhi Produk Domestik Regional Bruto Sektor Pertanian dan Industri Pengolahan}

Pertama pemilihan model terbaik antara CEM dan FEM dengan Uji Chow. Diperoleh nilai probability baik untuk sektor pertanian maupun industri pengolahan 0,0000 yang lebih kecil dari 0,05 sehingga keputusannya tolak $\mathrm{H}_{0}$ yang artinya FEM lebih baik dari CEM. Selanjutnya, pemilihan model terbaik antara FEM dan REM dengan Uji Hausman. Diperoleh nilai probability untuk sektor pertanian 0,0000 dan industri pengolahan 0,0366 yang masing-masing lebih kecil dari 0,05 sehingga keputusannya tolak $\mathrm{H}_{0}$ yang berarti FEM lebih baik daripada REM. Jadi, FEM merupakan model terbaik yang terpilih dalam penelitian ini.

Selanjutnya pemeriksaan struktur varians-kovarians residual. Pengujian dengan Uji Lagrange Multiplier diperoleh hasil untuk sektor pertanian 29,0146 dan industri pengolahan 29,0133 masing-masing lebih besar dari nilai chi-square tabel 19,6751 sehingga keputusannya tolak $\mathrm{H}_{0}$ yang berarti struktur varians-kovarians residual bersifat heteroskedastik. Kemudian pengujian dengan uji $\lambda_{\text {LM }}$ diperoleh hasil untuk sektor pertanian 168.1433 dan industri pengolahan 102,6344 masing-masing lebih besar dari nilai chi-square tabel 85,9649 sehingga keputusannya tolak $\mathrm{H}_{0}$ yang berarti terdapat cross sectional correlation antar kabupaten/kota di Provinsi Riau. Berdasarkan hasil pengujian, struktur varians-kovarians residual FEM bersifat heteroskedastik dan terdapat cross sectional correlation antar kabupaten/kota maka metode estimasi yang tepat adalah SUR.

Pengujian asumsi untuk model FEM adalah normalitas dan nonmultikolinearitas. Pengujian normalitas dengan uji Jarque-Bera diperoleh hasil untuk sektor pertanian 4,3247 dan sektor industri pengolahan 2,5886. Probability kedua sektor lebih besar dari 0,05 sehingga keputusannya gagal tolak $\mathrm{H}_{0}$ yang berarti residual kedua sektor tersebut berdistribusi normal. Selanjutnya, pemeriksaan nonmultikolinearitas yang menghasilkan nilai VIF lebih kecil dari 10 yang artinya tidak terjadi multikolinearitas antar variabel bebas.

Beberapa variabel yang digunakan dilakukan transformasi logaritma natural agar asumsi klasik terpenuhi, sehingga persamaan yang diperoleh adalah :

Sektor Pertanian :

Sektor Industri Pengolahan :

$$
\begin{aligned}
\ln \widehat{P D R} B A_{i t}= & \left(8,7393+\hat{\mu}_{i}\right)+0,00000125 T K A_{i t}-0,0122 I^{\prime N F} A_{i t} \\
& --0,0580 \ln L_{A H A N_{i t}}+0,1068 \ln \mathrm{JALAN}_{i t}
\end{aligned}
$$

$$
\begin{aligned}
\ln \widehat{P D R} B C_{i t}= & \left(10,5396+\hat{\mu}_{i}\right)+0,0296 \ln T K C_{i t}-0,0193 \operatorname{INFC}_{i t} \\
& +0,0691 \ln U_{S A H A}-0,2305 \ln \mathrm{JALAN}_{i t}
\end{aligned}
$$

Keterangan:

PDRBA : Produk Domestik Regional Bruto Sektor Pertanian (Miliar Rupiah)

PDRBC : Produk Domestik Regional Bruto Sektor Industri Pengolahan (Miliar Rupiah)

TKA : Tenaga Kerja Sektor Pertanian

TKC : Tenaga Kerja Sektor Industri Pengolahan

INFA : Inflasi Sektor Pertanian (\%)

INFC : Inflasi Sektor Industri Pengolahan (\%)

LAHAN: Luas Lahan Pertanian (Ha)

USAHA: Jumlah Unit Usaha

JALAN : Panjang Jalan (Km)

$\hat{\mu}_{i} \quad$ : Efek Cross Section

\section{Sektor Pertanian}

Secara simultan menghasilkan probability 0,0000 yang lebih kecil dari 0,05 sehingga menghasilkan keputusan tolak $\mathrm{H}_{0}$ yang berarti terdapat minimal satu variabel bebas memiliki pengaruh yang signifikan terhadap PDRB sektor pertanian. Kemudian, $R$-Square pada model ini sebesar 0,9997 yang berarti proporsi keragaman PDRB sektor pertanian yang mampu dijelaskan variabel bebas sebesar 99,97 persen.

Tenaga kerja sektor pertanian memiliki pengaruh positif dan signifikan terhadap PDRB sektor pertanian. Hal ini tercermin dari probability 0,0003 yang lebih kecil dari 0,05. Nilai koefisien 0,00000125 berarti setiap kenaikan 1 tenaga kerja sektor pertanian akan meningkatkan PDRB sektor pertanian 0,00000125 persen. Tenaga kerja sangat dibutuhkan dalam proses pertanian mulai dari penanaman, perawatan, hingga panen. Dachi (2016) penambahan tenaga kerja akan meningkatkan produksi pertanian. 
Inflasi sektor pertanian memiliki pengaruh negatif dan signifikan terhadap PDRB sektor pertanian. Hal ini tercermin dari probability 0,0000 yang lebih kecil dari 0,05. Nilai koefisien $-0,0122$ artinya setiap kenaikan 1 persen inflasi sektor pertanian, maka akan menurunkan PDRB sektor pertanian 0,0122 persen. Izzah (2015) naiknya harga secara berkelanjutan membuat produksi sulit dijangkau oleh semua kalangan. Inflasi yang tinggi akan berpengaruh terhadap kenaikan harga barang di pasaran sehingga daya beli masyarakat menurun yang menyebabkan PDRB juga menurun.

Luas lahan pertanian berpengaruh negatif dan signifikan terhadap PDRB sektor pertanian. Hal ini dilihat dari probability 0,0454 yang lebih kecil dari 0,05. Nilai koefisien -0,0580 artinya setiap kenaikan 1 persen luas lahan pertanian akan menurunkan PDRB sektor pertanian 0,0580 persen. Rencana Strategis Dinas Perkebunan Provinsi Riau tahun 2020-2024 benih berkualitas, pola dan jarak tanaman, perawatan dari hama penyakit serta pemupukan tanaman masih sangat rendah dilakukan. Beberapa daerah hilir mengalami kerusakan pada tanggul, saluran, dan pintu klep sehingga menyebabkan intrusi air laut. Air laut yang masuk menyebabkan sifat kimia, fisik dan biologi tanah jadi rusak dan membuat pertanian dan perkebunan akan rusak dan sulit untuk berkembang.

Panjang jalan tidak berpengaruh signifikan terhadap PDRB sektor pertanian. Hal ini dilihat dari probability 0,1188 yang lebih besar dari 0,05. Hasil yang sama pada penelitian Arindini (2018) dimana jalan tidak berpengaruh signifikan terhadap PDRB karena sebagian besar kondisi jalan rusak terjadi pada jalan kabupaten/kota sehingga berdampak pada distribusi hasil produksi yang tidak efisien.

\section{Sektor Industri Pengolahan}

Secara simultan menghasilkan probability 0,0000 yang lebih kecil dari 0,05 sehingga keputusannya tolak $\mathrm{H}_{0}$ yang artinya terdapat minimal satu variabel bebas yang memiliki pengaruh yang signifikan terhadap PDRB sektor industri pengolahan. Kemudian, R-Square pada model ini sebesar 0,9965 yang berarti proporsi keragaman PDRB sektor industri pengolahan yang mampu dijelaskan variabel bebas sebesar 99,65 persen.

Tenaga kerja sektor industri pengolahan memiliki pengaruh positif, namun tidak signifikan terhadap PDRB sektor industri pengolahan. Hal tersebut tercermin dari probability 0,0704 yang lebih besar dari 0,05. Akan tetapi, jika menggunakan tingkat signifikansi 10 persen, tenaga kerja memiliki pengaruh yang signifikan. Nilai koefisien sebesar 0,0296 artinya setiap kenaikan 1 persen tenaga kerja sektor industri pengolahan, maka akan meningkatkan PDRB sektor industri pengolahan 0,0296 persen. Sebagai salah satu faktor produksi tenaga kerja bertugas menggerakkan, menjalankan, dan mengoperasikan seluruh sumber produksi. Kusminarti et al. (2015) peningkatan tenaga kerja mengakibatkan produktivitas industri pengolahan meningkat.

Inflasi sektor industri pengolahan berpengaruh negatif dan signifikan terhadap PDRB sektor industri pengolahan. Hal tersebut tercermin dari probability 0,0000 yang lebih kecil dari 0,05 . Nilai koefisien-0,0193 artinya setiap kenaikan 1 persen inflasi sektor industri pengolahan akan menurunkan PDRB sektor industri pengolahan 0,0193 persen. Pranata (2014) laju inflasi yang tinggi mengakibatkan produksi suatu industri akan mengalami penurunan sebab harga bahan baku produksi akan semakin naik juga. Harga yang mengalami kenaikan terus-menerus menyebabkan harga tidak terjangkau oleh semua kalangan, terlebih lagi masyarakat yang berpenghasilan menengah ke bawah.

Jumlah unit usaha berpengaruh positif dan signifikan terhadap PDRB sektor industri pengolahan. Hal ini dilihat dari probability 0,0002 yang lebih kecil dari 0,05. Nilai koefisien 0,0691 artinya setiap kenaikan 1 persen jumlah unit usaha akan meningkatkan PDRB sektor industri pengolahan 0,0691 persen. Yusnanto (2010) semakin meningkatnya jumlah perusahaan, maka jumlah tenaga kerja juga meningkat sehingga pendapatan masyarakat akan meningkatkan.

Panjang jalan tidak berpengaruh signifikan terhadap PDRB sektor industri pengolahan. Hal ini dilihat dari probability 0,1361 yang lebih besar dari 0,05. Arindini (2018) jalan tidak berpengaruh signifikan terhadap PDRB karena sebagian besar kondisi jalan rusak terjadi pada jalan kabupaten/kota sehingga berdampak pada distribusi hasil produksi tidak efisien.

\section{KESIMPULAN}

Berdasarkan hasil penelitian disimpulkan bahwa sektor unggulan Provinsi Riau yaitu sektor pertanian dan sektor industri pengolahan. Selama periode 2015-2019, baik PDRB sektor pertanian maupun industri pengolahan selalu mengalami peningkatan di seluruh kabupaten/kota Provinsi Riau. Variabel lain seperti tenaga kerja sektor pertanian, inflasi sektor pertanian, luas lahan pertanian, tenaga kerja sektor industri pengolahan, inflasi sektor industri pengolahan dan jumlah unit mengalami trend yang fluktuatif. Sedangkan variabel panjang jalan cenderung tidak berubah. Variabel yang berpengaruh positif dan signifikan terhadap 
PDRB sektor pertanian Provinsi Riau tahun 2015-2019 adalah tenaga kerja sektor pertanian. Sementara itu, variabel inflasi sektor pertanian dan luas lahan pertanian memberikan pengaruh negatif dan signifikan. Sedangkan variabel panjang jalan tidak signifikan berpengaruh. Kemudian pada PDRB sektor industri pengolahan, variabel yang berpengaruh positif dan signifikan adalah tenaga kerja sektor industri pengolahan dan jumlah unit usaha. Sementara itu, variabel inflasi sektor industri pengolahan memberikan pengaruh negatif dan signifikan. Sedangkan variabel panjang jalan tidak signifikan berpengaruh

\section{DAFTAR PUSTAKA}

Arindini, U. S. (2018). Pengaruh Pembangunan Infrastruktur Jalan, Listrik, dan PMA Terhadap PDRB Daerah Istimewa Yogyakarta Periode Tahun 2004-2016 [Skripsi]. Yogyakarta : Universitas Islam Indonesia.

Ardiansyah, H. (2017). Pengaruh Inflasi Terhadap Pertumbuhan Ekonomi Di Indonesia. Jurnal Pendidikan Ekonomi, 5(3).

Baltagi, B. H. (2005). Econometric Analysis of Panel Data ( $3^{\text {th }}$ ed). London : John Wiley \& Sons, Ltd.

Basuki, A.T., \& Gayatri, U. (2009). Penentu Sektor Unggulan Dalam Pembangunan Daerah: Studi Kasus di Kabupaten Ogan Komering Hilir. Jurnal Ekonomi dan Studi Pembangunan. 10(1), 34-50.

Dachi, B.I. (2016). Analisis Faktor-Faktor yang Mempengaruhi Pertumbuhan Sektor Pertanian di Provinsi Sumatera Utara [Skripsi]. Medan: Universitas Sumatera Utara.

Izzah, N. (2015). Analisis Pengaruh Indeks Pembangunan Manusia (IPM) dan Inflasi Terhadap Pertumbuhan Ekonomi di Provinsi Riau Tahun 1994-2013. Jurnal Ekonomi Dan Bisnis Islam, 1(2), 156-172.

Kantor Staf Presiden \& Kementerian Komunikasi dan Informatika. (2019). Lima Tahun Maju Bersama. Kantor Staf Presiden.

Kusminarti, E., Hadi, T., \& Santoso, E. (2015). Jawa Timur An Analysis Influence Of Investment And Labour To The Sectors Of Manufacturing Industries In East Java. Jurnal Ilmu Ekonomi Dan Pembangunan, 1-7.

Pranata, C. B. (2014). Analisis Faktor-Faktor Yang Mempengaruhi Pdrb Sektor Industri Pengolahan Pada 33 Provinsi Di Indonesia Tahun 2009-2012 [Skripsi]. Semarang: Universitas Negeri Semarang.

Ratnasari, E. D. (2014). Sectors Analysis and Determination of Gdp Forming Leading Sector In District Kebumen. Jurnal Fokus Bisnis, 13(01), 1-29

Rokhmat, A., Hadi, S., SBM, N., \& Yusuf, E. (2020). Analisis Pengaruh Pembangunan Infrastruktur Pelayanan Dasar, Jalan Provinsi, Air Bersih, Hotel, Penginapan dan Restoran Terhadap Produk Domestik Regional Bruto. Jurnal Riset Ekonomi Dan Bisnis, 13(2).

Samuelson, P. A., \& Nurdhous, W. D. (2010). Economics (19th ed). New Delhi : McGraw-Hill

Sitorus, R. F. (2019). Pengaruh Luas Lahan dan Jumlah Produksi Kelapa Sawit Terhadap Produk Domestik Regional Bruto (PDRB) Sub Sektor Perkebunan di Kabupaten Asahan [Skripsi]. Medan : Universitas Islam Negeri Sumatera Utara Medan.

Syarifuddin, H., \& Dewi, R. M. (2014). Analisis Sektor Basis dan Nonbasis Terhadap Penyerapan Tenaga Kerja di Kabupaten Mojokerto Tahun 2003-2012. Jurnal Pendidikan Ekonomi. 2(3), 1-19.

Yusnanto. (2010). Analisis Faktor-Faktor Yang Mempengaruhi Sektor Industri Pengolahan Di Kabupaten Sukoharjo [Skripsi]. Surakarta : Universitas Sebelas Maret

Yusuf, Maulana. (1999). Model Rasio Pertumbuhan (MRP) sebagai Salah Satu Alat Analisis Alternatif dalam Perencanaan Wilayah dan Kota. Aplikasi Model: Wilayah Bangka-Belitung. Jurnal Ekonomi dan Keuangan Indonesia. 47(2), 219-233. 